\title{
Hand-foot-genital syndrome
}

INSERM

\section{Source}

INSERM. (1999). Orphanet: an online rare disease and orphan drug data base. Handfoot-genital syndrome. ORPHA:2438

Hand-foot-genital syndrome (HFGS) is a very rare multiple cong enital abnormality syndrome characterized by distal limb malformations and urogenital defects. 